\title{
Environmental Hydraulics Research
}

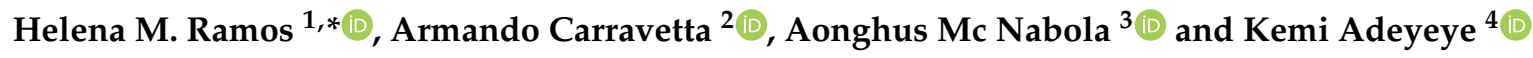 \\ 1 Department of Civil Engineering and Architecture, CERIS, Instituto Superior Técnico, University of Lisbon, \\ 1049-001 Lisbon, Portugal \\ 2 Department of Civil, Architecture and Environmental Engineering, University Federico II of Naples, \\ 80125 Naples, Italy; armando.carravetta@unina.it \\ 3 Department of Civil, Structural and Environmental Engineering, Trinity College Dublin, \\ D02 PN40 Dublin, Ireland; amcnabol@tcd.ie \\ 4 Department of Architecture \& Civil Engineering, University of Bath, Claverton Down, Bath BA2 7AY, UK; \\ K.Adeyeye@bath.ac.uk \\ * Correspondence: hramos.ist@gmail.com or helena.ramos@tecnico.ulisboa.pt
}

Received: 29 September 2020; Accepted: 30 September 2020; Published: 1 October 2020

check for updates

\begin{abstract}
Environmental hydraulics research includes the different domains of hydrodynamics, such as the investigation and implementation of the physical and experimental applications, and research into the quantity, quality, modelling and simulation of the attributes associated with flowing water. This topic is studied both from a technical and environmental point of view, with the objective of protecting and enhancing the quality of the environment. It is a cross-disciplinary field of study which comprises open channel/river flows and pressurised systems, combining, among others, new technological, social, and environmental hydraulic challenges. It provides researchers and engineers working in water-related fields with available information, new concepts and tools, new design solutions, eco-friendly technologies, and the advanced materials necessary to address the increasing challenges of ensuring a sustainable water environment-that is, a water environment effectively managed and adequated for generations to come by promoting the adaptation, flexibility, integration and sustainability of recognised environmental solutions. Using advanced numerical and physical models in field experiments, and tests in different types of laboratory set-ups, specialists in environmental hydraulics produce the best analyses, concepts, techniques, tools, and solutions to environmental hydraulic problems, as well as in relation to the water, energy and environmental nexus.
\end{abstract}

Keywords: new hydraulic concepts; sustainable developments; CFD models; water systems efficiency; hydropower systems; eco-design; environmentally-friendly solutions; hydrologic and ecologic challenges; hydraulic structures; free surface flows; pressurised flows; soil structure; groundwater; erosion and energy dissipaters; hydrodynamics

\section{Introduction}

Environmental hydraulics research includes the different domains of hydrodynamics, such as the investigation and implementation of the physical and experimental applications, and research into the quantity, quality, modelling and simulation of the characteristics associated with water flow. Using advanced numerical and physical models in field experiments, and tests in different types of laboratory set-ups, specialists in environmental hydraulics present the best analyses, new design concepts, apply different nature-friendly techniques, use advanced simulation tools, and obtain friendly solutions to environmental hydraulic problems as well as for water, soil, civil works, energy dissipaters and to produce devices and complex hydraulic phenomena under an integrated environmental nexus.

This Special Issue addresses environmental hydraulics as an environmental continuum of water, air and soil, focussing on the motion of liquid at the macroscopic scale [1]. It considers 
groundwater, hydraulic structures, spillways, stormwater infrastructures, erosion problems, river and lake interactions, energy dissipaters, river bed and scour processes, water-energy potential, as well as the water, soil and ecosystem issues pertaining to hydrological activities and events, water quality and all hydraulic activities and investigations within natural and non-natural water domains. Of note in this Special Issue is the essential role of pumped-storage hydropower systems as a flexible renewable energy source, especially when integrated with wind and solar energy sources [2]. Hydropower is one of the oldest energy sources developed by humankind and continues to also be one of the most prominent ones in terms of cost, as well as social and environmental impacts. However, the use of hydropower requires a more flexible, efficient, environmentally and socially friendly and acceptable approach to complement wind and solar energy production, in particular by (i) increasing hydropower production through the implementation of new environmentally friendly multipurpose hydropower schemes and by using the hidden potential in existing water infrastructures, (ii) increasing the flexibility of generation from existing hydropower plants by adaptation and optimization of infrastructures and equipment combined with innovative solutions for the mitigation of environmental impacts and (iii) increasing storage by the construction of new reservoirs, which have to ensure not only flexible energy supply but also support the food and water nexus [3-6]. Therefore, a hybrid system comprised of several renewable energy resources of a complementary nature working alongside other sources in an integrated and flexible way is of utmost importance in the electric production system and energy management.

\section{Main Subjects Analysed}

This book comprises research papers which address the different approaches, advanced studies and practice tools for environmental hydraulics. The works presented in this Special Issue cover the following main themes, as described below:

1. In cold regions, hydraulic conductivity is a critical parameter for determining the water flow in frozen soil. Previous studies have shown that hydraulic conductivity hinges on the pore structure, which is often depicted as the pore size and porosity. However, these two parameters do not sufficiently represent the pore structure $[7,8]$. To enhance the characterization ability of the pore structure, one study introduces fractal theory to investigate the influence of pore structure on hydraulic conductivity. Phosphorus is a major cause of lake eutrophication. Understanding the characteristics regarding the release of phosphorus from sediments under hydrodynamic conditions is crucial for the regulation of lake water quality.

2. Water wells play an increasingly important role in providing water for the civilian population all over the world. The number of boreholes is increasing not only due to population growth, but also due to a decrease in the productivity of the existing assets. Like other engineering structures, wells are subject to ageing processes resulting in degradation, which is observed as a reduction in hydraulic efficiency throughout their lifespan. Hydraulic conductivity hinges on the pore structure, which is often depicted as the pore size and porosity. Unlike "sustainable yield", for the concept of efficiency, compensation is not a constant-rate or constant-head method. The "sustainable efficiency" concept requires the regulation of both flow rate and drawdown. The authors in $[9,10]$ investigate the problems associated with the drilling of groundwater wells.

3. Lakes provide valuable ecosystem services for riparian communities and play an important role in sustaining ecological security and sustainable development. Hence, the effects of sediment suspension on the release characteristics of phosphorus from sediment are analysed.

4. Reusing stormwater is more critical in water-scarce regions and regions where rainfall patterns and rainfall frequencies are changing [5]. Several regions are trying to reuse stormwater as a sustainable method of water resource management; thus, timely research into the feasibility of reusing stormwater from a water quality perspective is presented in [11]. The Soil Conservation Service (SCS) curve number model is used as the basis of an integrated hydrological-CFD model 
to generate flow rates from the watershed draining into rain ponds due to storms and estimating bacterial levels in storm water ponds. An experimental investigation of the erosion characteristics of fine-grained cohesive sediments is used to model the transport of fine sediment and the associated nutrients in a river system. The erosion experimental data allowed the identification of the critical shear stress for erosion. Urban stormwater, as an important environmental problem, requires us to find green infrastructure solutions, which provide water treatment and retention at the same time. Floating treatment wetlands, which are porous patches that continue down from the free surface with a gap between the patch and bed, are innovative instruments for nutrient management in lakes, ponds, and slow-flowing waters.

5. Lakes are important for global ecological balance and provide rich biological and social resources, but they are sensitive to climate change and anthropogenic activities in which river-reservoir erosion and the water level can be affected by an existing dam operation. Fish protection and downstream migration measures are also considered essential in the hydraulic design, construction or retrofitting and operation of hydropower plants. Since downstream migrating fish, particularly juveniles, tend to swim within the main current, they will consequently pass the turbines if appropriate measures are not put in place at the water intake [12]. Different types of spur dikes, such as rock fill, permeable, $\mathrm{w}$-shaped rock fill, and $\mathrm{w}$-shaped permeable are evaluated using flume experiments for spur dike hydrodynamics and fish aggregation effects. The results could provide theoretical support for habitat heterogeneity research and the ecologically optimal design of spur dikes. The effects of changes in the angle of the pool impact plate, plunging depth, and discharge upon the dynamic pressure caused by ski jump buckets are investigated in the laboratory. Due to dynamic pressures resulting from the flow in hydraulic structures, the riverbed is frequently affected by scouring. Moreover, many lakes are connected to rivers to form complicated river-lake systems [13-15]. As a safe device in a dam, the understanding of jet features is crucial in designing the pool and determining the plunging rate [16]. Recently, many researchers and engineers have also studied the ecological effects of spur dikes through model tests, numerical simulations and on-site observations. The results in [17-19] show that spur dikes can enhance river habitat heterogeneity and improve the suitability of fish habitats under low and medium water flows. In hydropower, the requirements for fish protection at hydro power plants have led to a significant decrease in the bar spacing at trash racks, as well as the need for an inclined or angled design to improve the guidance effect using a fish-friendly trash rack.

6. In a water system where an excess of internal energy needs to be dissipated effectively, a specific dissipater reduces the downstream flow speed, smoothly connects the downstream flow, and avoids the erosion of the river channel in a well-defined water conveyance project described in [20-22]. On the other hand, the toothed internal energy dissipater is a new type of dissipater that controls the excess flow energy. However, in the open-channel control algorithm, good feedforward controllers will reduce the transition time of the canal and improve its performance. Hybrid pumped hydro storage energy solutions with wind and PV integration present further improvements in flexibility, reliability and in the associated energy costs. A technique based on a multi-criteria evaluation, for a sustainable environmental solution based on renewable source integration, is presented, with the results demonstrating that, technically, pumped hydro storage with wind and PV is an ideal solution to achieve energy autonomy and to increase flexibility and reliability. A hydrostatic pressure machine is also analysed using CFD modelling with detailed characterization and evaluation, with promising results [23]. Another study recently examined a technology based on a transient flow-induced compressed air energy storage system, which takes advantage of a compressed air vessel to combine pumping and hydropower solutions.

The importance of environments in rivers and pipe systems are not overstated. They provide water, energy and food, safety and better controlled systems. They can cause major damage through flooding and erosion, and they are the means to avoid water scarcity or a lack of quality. Therefore, 
engineering needs a solid understanding of the mechanics governing phenomena. This book provides readers with necessary knowledge about eco-design developments and troubleshoots a variety of environmental hydraulic engineering works. It analyses the fascinating hydraulics of rivers, including the interactions between sediment (e.g., sand, gravel) and water flow, erosion and scour problems, engineering intervention in river and lakes, in fish protection infrastructures, in storm water sustainable management, in eco-friendly solutions, in flood modelling and mitigation, hydropower renewable integration systems, embankments, dams or dikes and spillways and jet effects in relation to hydraulic-ecological effects. Environmental issues are presented in the wider context of civil engineering and environmental hydraulics via computer-based studies, and laboratory or field results.

Author Contributions: H.M.R. conceived and led the development of this Special Issue and this editorial; A.C., A.M.N. and K.A. contributed substantially to the writing. All authors have read and agreed to the published version of the manuscript.

Acknowledgments: The authors of this editorial, who served as guest editors of this Special Issue, wish to thank the journal editors, all authors submitting papers to this Special Issue, and the many referees who contributed to paper revision and the improvement of all published articles.

Conflicts of Interest: The authors declare no conflict of interest.

\section{References}

1. Singh, V.P.; Hager, W.H. What is Environmental Hydraulics. In Environmental Hydraulics; Springer: Dordrecht, The Netherlands, 1996; pp. 1-5.

2. Vieira, F.; Ramos, H.M. Hybrid solution and pump-storage optimization in water supply system effciency: A case study. Energy Policy 2008, 36, 4142-4148. [CrossRef]

3. Carravetta, S.A.; Ramos, H.M.; Houreh, S.D. Pumps as Turbines, Fundamentals and Applications; Springer International Publishing: Berlin/Heidelberg, Germany, 2018.

4. Jaramillo-Duque, Á.; Castronuovo, E.D.; Sánchez, I.; Usaola, J. Optimal operation of a pumped-storage hydro plant that compensates the imbalances of a wind power producer. Electr. Power Syst. Res. 2011, 81, 1767-1777. [CrossRef]

5. International Hydropower Association (IHA). The World's Water Battery: Pumped Hydropower Storage and the Clean Energy Transition; IHA Working Paper; International Hydropower Association: London, UK, 2018.

6. International Hydropower Association (IHA). Pumped Storage Hydropower Has 'Crucial Role' in Europe's Energy Strategy; IHA Working Paper; International Hydropower Association: London, UK, 2020.

7. Tao, G.L.; Zhu, X.L.; Hu, Q.Z.; Zhuang, X.S.; He, J.; Chen, Y. Critical pore-size phenomenon and intrinsic fractal characteristic of clay in the process of compression. Rock Soil Mech. 2019, 40, 81-90.

8. Xiao, B.; Fan, J.; Ding, F. A fractal analytical model for the permeabilities of fibrous gas diffusion layer in proton exchange membrane fuel cells. Electrochim. Acta 2014, 134, 222-231. [CrossRef]

9. Walton, W.C. Ground-Water Hydraulics as an Aid to Geologic Interpretation. Ohio J. Sci. 1955, 55, 13-20.

10. Dufresne, D.P. Developing Better Regional Groundwater Flow Models with Effective Use of Step-Drawdown Test Results. Fla. Water Resour. J. 2011, 63, 36-40.

11. Ahilan, S.; Guan, M.; Wright, N.; Sleigh, A.; Allen, D.; Arthur, S.; Haynes, H.; Krivtsov, V. Modelling the long-term suspended sedimentological effects on stormwater pond performance in an urban catchment. J. Hydrol. 2019, 571, 805-818. [CrossRef]

12. Clevenot, L.; Carré, C.; Pech, P. A Review of the factors that determine whether stormwater ponds are ecological traps and/or high-quality breeding sites for amphibians. Front. Ecol. Evol. 2018, 6, 40. [CrossRef]

13. Böttcher, H.; Gabl, R.; Ritsch, S.; Aufleger, M. Experimental study of head loss through an angled fish protection system. In Proceedings of the 4th IAHR Europe Congress, Liege, Belgium, 27-29 July 2016; pp. 637-642.

14. Yao, J.; Zhang, Q.; Li, Y.L.; Li, M.F. Hydrological evidence and cause of seasonal low water levels in a large river-lake system: Poyang Lake, China. Hydrol. Res. 2016, 47, 24-39. [CrossRef]

15. Pu, J.H.; Huang, Y.F.; Shao, S.D.; Hussain, K. Three-Gorges Dam Fine Sediment Pollutant Transport: Turbulence SPH Model Simulation of Multi-Fluid Flows. J. Appl. Fluid Mech. 2016, 9, 1-10. [CrossRef] 
16. Huang, G.X.; Zhou, J.J.; Lin, B.L.; Xu, X.F.; Zhang, S.H. Modelling flow in the middle and lower Yangtze River, China. Water Manag. 2016, 170, 298-309. [CrossRef]

17. Mahmoud, H.; Kriaa, W.; Mhiri, H.; Le Palec, G.; Bournot, P. Numerical analysis of recirculation bubble sizes of turbulent co-flowing jet. Eng. Appl. Comput. Fluid. 2012, 6, 58-73. [CrossRef]

18. Chakravarti, A.; Jain, R.K.; Kothyari, U.C. Scour under submerged circular vertical jets in cohesionless sediments. ISH J. Hydraul. Eng. 2014, 20, 32-37. [CrossRef]

19. Yin, Z.; Shi, B.; Zhao, L.; Sun, D. Numerical simulation of plug energy dissipater flow. Adv. Water Sci. 2008, 1, 89-93.

20. Wang, Z.; Wu, B.; Wang, G. Fluvial processes and morphological response in the Yellow and Weihe Rivers to closure and operation of Sanmenxia Dam. Geomorphology 2007, 91, 65-79. [CrossRef]

21. Lian, L.; Wang, W.; Tian, Z. Characteristics of energy dissipation and cavitation for complex plug in discharge tunnel. J. Hydroelectr. Eng. 2012, 2, 62-70.

22. Rydlewicz, W.; Rydlewicz, M.; Pałczyński, T. Experimental investigation of the influence of an orifice plate on the pressure pulsation amplitude in the pulsating flow in a straight pipe. Mech. Syst. Signal Process. 2019, 117, 634-652. [CrossRef]

23. Senior, J.; Saenger, N.; Müller, G. New hydropower converters for very low head differences. J. Hydraul. Res. 2010, 48, 703-714. [CrossRef]

(C) 2020 by the authors. Licensee MDPI, Basel, Switzerland. This article is an open access article distributed under the terms and conditions of the Creative Commons Attribution (CC BY) license (http://creativecommons.org/licenses/by/4.0/). 